\title{
TEKNOLOGI PEMBUATAN TELUR ASIN SELAMA 3 JAM MELALUI MANIPULASI TEKANAN OSMOTIK
}

\author{
JOKO SUSILO \\ SMA NEGERI 1 PLUPUH \\ paksus73@gmail.com
}

\begin{abstract}
Sragen is one of the districts in Surakarta residency whose territory consists of agricultural land located along the river Bengawan Solo. The livelihoods of the community are mostly farmers. One of them is engaged in duck farms located in the subdistricts of Plupuh, Masaran and Sidoharjo. Duck breeders in this region who supply the needs of salted eggs in sragen region.

Nutrition needs of the community needs to be improved in order to support the continuity of national pembanagunan. Egg needs as a source of protein is needed by the body, one of which comes from duck eggs.

The process of making salted eggs derived from duck eggs during this time requires a long time of about 14 days or two weeks, so the value of productivity is low. Salted egg resistance made for 7 days about two weeks from the cooking process, because the water content is still high enough to facilitate quickly decay

To increase the value of productivity need a new breakthrough for the process of making salted eggs. Among them by using appropriate technology that requires relatively small operational costs that can be made by anyone. This breakthrough can be done by manipulating the osmotic pressure factor in the process of making salted eggs. The technology of making salted egg for 3 hours through osmotic pressure manipulation can be done briefly and durability of salted egg is longer that is up to 15 days from the process of manufacture. Because the manufacturing process does not require a lot of water so that the water entering is relatively smaller.

Based on our research, "The Technology of Making Salted Eggs For 3 Hours Through Osmotic Pressure Manipulation" proved to have high productivity and endurance value than is often done so far by the home production of salted eggs in the community.
\end{abstract}

\section{Keywords: Making 3-hour Salted Eggs, Osmotic pressure, Old resistant.}

\begin{abstract}
ABSTRAK
Sragen merupakan salah satu kabupaten di karisidenan Surakarta yang wilayahnya terdiri dari lahan pertanian yang berada di sepanjang sungai Bengawan Solo. Mata pencaharian masyarakatnya mayoritas petani . Salah satunya bergerak dalam bidang peternakan bebek yang berada di wilayah kecamatan Plupuh, Masaran dan Sidoharjo. Peternak Bebek di wilayah ini yang menyuplai kebutuhan telur asin di wilayah sragen.

Kebutuhan Gizi masyarakat perlu ditingkatkan guna menunjang kelangsungan pembanagunan nasional . Kebutuhan telur sebagai sumber protein sangat dibutuhkan oleh tubuh, salah satunya bersumber dari telur bebek.

Proses pembuatan telur asin yang berasal dari telur bebek selama ini memerlukan waktu yang cukup lama sekitar 14 hari atau dua minggu, sehingga nilai produktivitasnya rendah. Daya tahan telur asin yang dibuat selama 7 hari sekitar dua
\end{abstract}


minggu dari proses pemasakan, karena kadar airnya masih cukup tinggi sehingga memudahkan cepat membusuk

Untuk meningkatkan nilai produktivitas perlu adanya terobosan baru untuk proses pembuatan telur asin. Diantaranya dengan menggunakan teknologi tepat guna yang memerlukan biaya operasional yang relatif kecil yang dapat dibuat oleh siapaun. Terobosan ini dapat dilakukan dengan cara memanipulasi factor tekanan osmotik dalam proses pembuatan telur asin. Teknologi pembuatan telur asin selama 3 jam melalui manipulasi tekanan osmotik ini dapat dilakukan secara singkat dan daya tahan telur asin lebih lama yaitu sampai 15 hari dari proses pembuatannya. Karena proses pembuatannya tidak memerlukan air yang banyak sehingga air yang masuk relatif lebih kecil.

Berdasarkan penelitian yang kami lakukan, "Teknologi Pembuatan Telur Asin Selama 3 Jam Melalui Manipulasi Tekanan Osmotik" terbukti mempunyai nilai produktifitas dan daya tahan yang tinggi dibanding yang sering dilakukan selama ini oleh rumah produksi telur asin di masyarakat.

\section{Kata Kunci : Pembuatan Telur Asin 3 Jam,tekanan Osmotik,tahan Lama.}

\section{PENDAHULUAN / LATAR BELAKANG}

Perkembangan zaman dan teknologi yang semakin canggih, merambat kepada setiap aspek kehidupan, tingkat persaingan yang semakin tinggi memaksa setiap orang lebih jeli dalam membaca setiap peluang dalam usaha mengembangkan keterampilan dan keahliannya untuk menjawab tantangan zaman. Rendahnya tingkat keterampilan dan keahlian yang dimiliki oleh sebagian besar penduduk Indonesia merupakan salah satu alasan kenapa angka pengangguran di Indonesia semakin meningkat. Padahal usaha yang dilakukan pemerintah dalam memberantas kemiskinan agenda utama dari pemerintah. Namun semua itu ternyata tidaklah cukup, karena belum didukung oleh sumber daya manusia yang terampil dan berkeahlian yang dapat dimanfaatkan untuk membuka peluang usaha, menciptakan lapangan kerja sendiri, atau berkreasi yang menghasilkan tentunya yang dapat berdampak pada penekanan terhadap tingginya angka pengangguran, tingginya angka kemiskinan yang ada di Indonesia tersebut.

Telur Asin adalah makanan yang senantiasa dapat digunakan sebagai lauk pauk ataupun hanya sekedar camilan, makanan yang satu ini tidak sedikit yangmenyukainya karena rasanya gurih dan agak sedikit asin. Makanan ini biasanya dibuat oleh industri rumahan yang banyak kita jumpai di berbagai daerah. Pembuatannya yang tidak terlalu sulit ini menarik minat banyak orang terutama di desa-desa yang lapangan pekerjaannya masih jarang

Usaha pembuatan telur asin adalah salah satu jenis industri makanan yang umumnya berskala mikro dan kecil. Bahan baku utama yang akan dijadikan telur asin adalah telur itik/bebek, sedangkan jenis telur lainnya tidak lazim dilakukan karena 
kebiasaan dari masyarakat kita yang menganggap telur asin berasal dari telur itik. Teknologi yang diperlukan untuk memproduksi telur asin secara umum merupakan teknologi yang sederhana. Oleh karena itu perbedaan proses produksi dan kualitas produk telur asin ditentukan berdasarkan cara pengolahannya.

Telur asin adalah istilah umum untuk masakan berbahan dasar telur yang diawetkan dengan cara diasinkan (diberikan garam berlebih untuk menonaktifkan enzim perombak). Kebanyakan telur yang diasinkan adalah telur itik, meski tidak menutup kemungkinan untuk telur-telur yang lain. Telur asin baik dikonsumsi dalam waktu satu bulan (30 hari).

\section{RUMUSAN MASALAH / IDENTIFIKASI MASALAH}

Pengawetan yang paling mudah dan sering dilakukan oleh masyarakat adalah dengan cara pengasinan atau pembuatan telur asin. Menurut Suharno dan Amri dalam Kautsar (2005), proses pengasinan telur memerlukan waktu selama 15 30 hari. Sedangkan proses pengasinan dengan larutan garam jenuh memerlukan waktu sekitar 7 - 10 hari (Suprapti, 2002 dalam Sultoni, 2004). Lama waktu proses tersebut masih menjadi permasalahan yang harus dipecahkan, karena selain lama perendaman erat kaitannya dengan efisiensi waktu proses pengasinan telur, juga erat kaitannya dengan karakteristik organoleptik telur asin yang dihasilkan.

Apakah telur asin dapat dibuat dalam waktu yang singkat dengan memanipulasi factor tekanan osmotik terutama faktor konsentrasi dan suhu? Apakah perendaman telur dalam asam cuka dapat membuka membran semipermeabel pada kulit telur sehingga larutan garam cepat masuk dalam telur?

\section{HIPOTESIS KAJIAN}

\subsection{Kerangka Berpikir}

Alur kerangka berpikir dalam penelitian ini adalah adanya permasalahan proses pembuatan telur asin yang membutuhkan waktu yang cukup lama yaitu sekitar 15 sampai dengan 21 hari. Penulis merasa waktu tersebut cukup lama, maka dari itu penulis mencoba membuat terobosan untuk mempersingkat waktu pembuatan dengan melihat kemampuan kecepatan tekanan osmotik untuk mempercepat proses pembuatan telur asin. Diharapkan proses ini lebih meningkatkan nilai produktivitas produksi telur asin . tekanan osmotic yang kami soroti yaitu factor suhu dan factor membuka sedikit membrane semi permeabel pada kulit telur dengan menggunakan asam cuka berbagai konsentrasi tertentu, kemudian hasil yang diperoleh diuji tingkat keasaman apakah dengan membuka membrane semipermeabel 
dengan asam cuka mempengaruhi kualitas telur asin . Berikut diagram kerangka berpikir penelitian ini

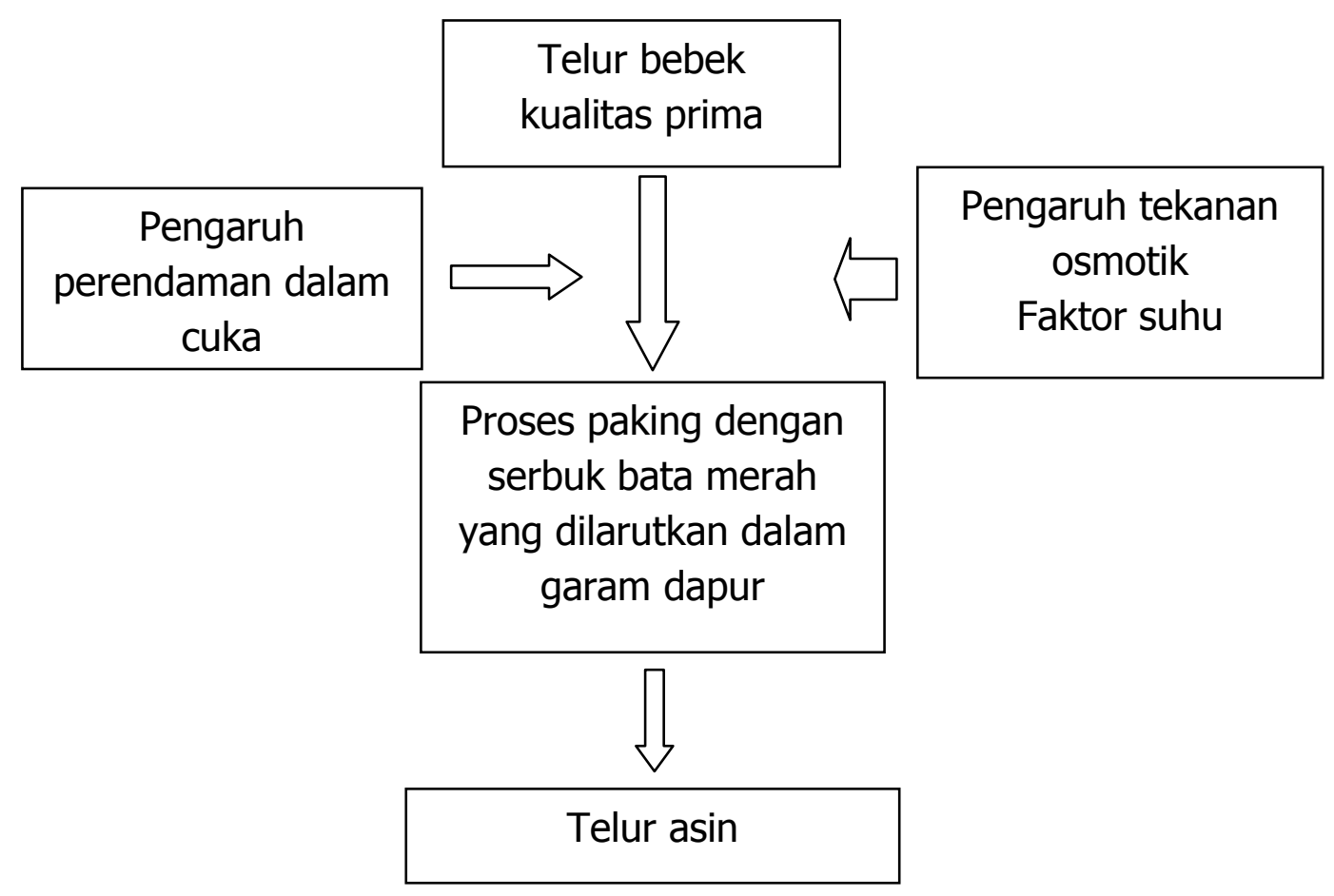

\subsection{Hipotesis}

Hipotesis dalam penelitian ini adalah :

A. Telur Asin dapat dibuat dalam waktu yang singkat melalui manipulasi faktor tekanan osmotik.

B. Perendaman telur dalam asam cuka dapat membuka membran semipermeabel pada kulit telur sehingga larutan garam cepat masuk dalam telur.

\section{TINJAUAN PUSTAKA}

\section{1. .Telur Asin}

Siapa yang gak tau telur asin? makanan yang umumnya dibuat dari bahan telur bebek ini memiliki cita rasa asin namun enak di lidah. Selain rasanya yang lezat, telur asin juga memiliki banyak kandungan gizi dan sangat baik untuk anak. Maka dari itu telur asin sangat baik untuk di jadikan lauk pendamping makanan anak.Makanan yang satu ini sangat mudah di jumpaii, biasanya dapat di beli di warung-warung. Namun taukah anda bahwa anda pun bisa membuat telur asin sendiri yang enak dan lezat. Ciri-ciri telur asin enak biasanya terlihat dari teksturnya yang "Masir" seperti pasir tidak menggumpal. 
Telur adalah salah satu sumber protein hewani yang memilik rasa yang lezat, mudah dicerna, dan bergizi tinggi. Selain itu telur mudah diperoleh dan harganya murah. Telur dapat dimanfaatkan sebagai lauk, bahan pencampur berbagai makanan, tepung telur, obat, dan lain sebagainya. Telur terdiri dari protein $13 \%$, lemak $12 \%$, serta vitamin, dan mineral. Nilai tertinggi telur terdapat pada bagian kuningnya. Kuning telur mengandung asam amino esensial yang dibutuhkan serta mineral seperti : besi, fosfor, sedikit kalsium, dan vitamin B kompleks. Sebagian protein (50\%) dan semua lemak terdapat pada kuning telur. Adapun putih telur yang jumlahnya sekitar $60 \%$ dari seluruh bulatan telur mengandung 5 jenis protein dan sedikit karbohidrat. telur. Macam-macam telur adalah telur ayam, telur bebek atau itik, telur puyuh dan lain-lain.

Telur itik mempunyai kandungan protein lebih banyak terdapat pada vagina kuning telur $17 \%$, sedangkan bagian putihnya terdiri dari ovalbumin (putih telur) dan ovavitelin (kuning telur). Sebutir telur mempunyai kegunaan protein (net protein utilization) $100 \%$ dibandingkan dengan daging ayam (80\%) dan susu (75\%). Berarti jumlah dan komposisi asam aminonya sangat lengkap dan berimbang, sehingga hampir seluruh bagiannya dapat digunakan untuk pertumbuhan maupun penggantian sel-sel yang rusak. Hampir semua lemak dalam sebutir telur itik terdapat pada bagian kuningnya, mencapai $35 \%$, sedangkan di bagian putihnya tidak ada sama sekali. lemak pada telur terdiri dari trigliserida (lemak netral), fosfolipida (umumnya berupa lesitin), dan kolesterol. Kandungan nilai gizi telur itik secara umum lebih tinggi dibandingkan dengan telur ayam. Dibanding telur segar mutu protein telur asin sudah agak menurun. Garam telah menggumpalkan proteinnya, sehingga penyerapannya di dalam tubuh tidak semudah penyerapan protein telur segar. Perbedaan ini dapat diamati dari konsistensi bagian kuning pada telur asin lebih keras daripada bagian kuning telur segar. Penurunan nutrisi yang terjadi selama penggaraman hanyalah pada kandungan betakarotennya yang cukup nyata. Satu-satunya nutrisi yang potensial hanyalah kalsium, karena kandungannya meningkat tajam dibanding telur segar. Nutrisi lain yang meningkat akibat pengasinan telur adalah kalsium. Hal ini tentu menguntungkan, karena kalsium sangat diperlukan dalam pembentukan tulang yang kuat. Kandungan kalsium meningkat 2,5 kali setelah pengasinan.

Perbandingan nilai gizi telur itik dan telur ayam dapat dilihat dalam tabel di bawah ini: 
Tabel 1. Data Nilai Gizi Telur Itik dan Telur Ayam Per 100 Gram Telur

\begin{tabular}{|l|l|l|l|l|l|l|}
\hline $\begin{array}{l}\text { Jenis } \\
\text { Telur }\end{array}$ & $\begin{array}{l}\text { Kalori } \\
(\mathbf{k k a l})\end{array}$ & $\begin{array}{l}\text { Lemak } \\
(\mathbf{g})\end{array}$ & $\begin{array}{l}\text { Protein } \\
(\mathbf{g})\end{array}$ & $\begin{array}{l}\text { Kalsium } \\
(\mathbf{m g})\end{array}$ & $\begin{array}{l}\text { Besi } \\
(\mathbf{m g})\end{array}$ & Vit.A(SI) \\
\hline Telur itik & 163 & 14.3 & 13.1 & 56 & 2.8 & 1230 \\
\hline $\begin{array}{l}\text { Telur } \\
\text { ayam }\end{array}$ & 189 & 11.5 & 12.8 & 54 & 2.7 & 900 \\
\hline
\end{tabular}

Sumber: Direktorat Gizi, Departemen Kesehatan

Kelemahan telur yaitu memiliki sifat mudah rusak, baik kerusakan alami, kimiawi maupun kerusakan akibat serangan mikroorganisme melalui pori-pori telur. Oleh sebab itu usaha pengawetan sangat penting untuk mempertahankan kualitas. Pengawetan telur dapat dilakukan dengan cara pengasian. Kulit telur (cangkang) tersusun atas senyawa kalsium karbonat $\left(\mathrm{CaCO}_{3}\right)$. Kulit ini berpori-pori, sehingga gas dan air dapat menembusnya. Sifat inilah menyebabkan telur dapat diasinkan. Telur itik yang mempunyai kandungan protein yang tinggi cocok untuk dilakukan pengasinan.

\subsection{Proses Pembuatan Telur Asin}

Ada 3 cara pembuatan telur asin :

1. Metode Perendaman dengan larutan air garam

Siapkan air dan tambahkan garam secukupnya. Aduk sampai garam larut. Lalu rendam telur yang sudah dibersihkan ke dalam larutan garam selama lebih kurang 10 hari dalam wadah yang tertutup. Jika menginginkan rasa telur yang lebih asin lagi, rendamlah telur lebih lama lagi.

2. Metode Perendaman dengan adonan garam

Siapkan adonan garam : berupa campuran air dan garam yang kekentalannya seperti pasta. Lalu susun telur, lalu siram dengan adonan pasta garam tersebut sampai tertutup semuanya. Simpan beberapa hari. Setelah itu siap untuk digunakan.

3. Metode Pemeraman Dengan adonan garam, batu bata dan abu gosok Campurkan abu gosok, batu merah yang sudah digiling halus dan garam. Aduk rata. Perbandingan campuran 2:2:3. Tambahkan air secukupnya sampai menjadi adonan pasta. Lalu balurkan ke telur sampai terbungkus rapi, kirakira dengan ketebalan adonan $1 \mathrm{~cm}$. Simpan ditempat yang terbuka sampai waktu yang diinginkan . Untuk asin yang tidak berlebihan penyimpanan dilakukan bisa selama 7-15 hari.

Terus, bagaimana mengetahui apakah telur asin yang kita beli itu palsu dan proses pembuatannya instan sehingga membahayakan kesehatan ? begini caranya :

1. Telur asin asli warna kuning telurnya biasanya keorenan/kemerahan. 
Kuning telurnya "masir". Kalau telur asin palsu kuning telurnya pucat karena dibuat dari telur ayam biasa .

2. Atau bisa dengan menggunakan cairan pemutih. Gosoklah telur secara perlahan, apabila warna terlihat kecoklatan itu artinya telur asin dibuat dari telur ayam yang sudah diwarnai dengan pewarna tekstil dan penguat warna lainnya yang bukan pewarna makanan.

3. Agar proses pembuatan telur asin tidak memakan waktu yang lama, cukup hanya memakan waktu 1 hari saja. Caranya : mereka merendam salah satu sisi ujung telur dengan cuka sampai telurnya melunak lalu penjual menyuntikkan air garam . Lalu telur ayam dicat dengan cat tembok setelah itu diberi tepung kanji sehingga warnanya sangat menyerupai telur bebek asli dan sekaligus menghilangkan guratan guratan cat pada telur . Cara untuk mengetahuinya, usaplah permukaan telur jika agak kesat dan warnanya agak kusam, itu artinya palsu.

\subsection{Tekanan Osmotik}

Suatu larutan yang encer memiliki tekanan uap yang lebih besar daripada larutan yang lebih pekat. Artinya,molekul-molekul pelarutdalam larutan encer memiliki kecenderungan lolos ke yang lebih besar.marilah kita amati apa yang terjadi jika suatu larutan yang encer dan suatu larutan yang pekat dipisahkan oleh selaput semipermeabel, yaitu selaput yang dapat dtembus oleh molekul pelarut, tetapi tidak dapat ditembus oleh molekul zat terlarut.selaput semipermeabel ini dapat berupagelatin, kertas perkamen,lapisan film selofan, membrane sel makhluk hidup seperti selaput pada telur. Maka terjadilah peristiwa osmosis.

Tekanan osmotik adalah proses mengalirnya molekul-molekul pelarut yang memiliki konsentrasi yang encer /rendah menuju konsentrasi yang lebih tinggi/ pekat melalui selaput semi permeabel. Menurut Raoult tekanan osmotik dirumuskan :

$$
\boldsymbol{\mu}=\mathbf{M R T}
$$

Keterangan :

$\mu=$ Tekanan osmotic larutan ( atm)

$\mathrm{M}=$ Konsentrasi larutan ( Molar )

$\mathrm{M}=$ gram/ $\mathrm{Mr} \times 1000 / \mathrm{V}$ atau $\mathrm{M}=10 . \mathrm{x} \% \mathrm{p} / \mathrm{Mr}$

$\mathrm{R}=$ konstanta gas $(0,082$ ) ( L.atm / mol. K )

$\mathrm{T}=$ Suhu mutlak $\left({ }^{0} \mathrm{~K}\right)$ 


\section{METODE KAJIAN}

\subsection{Jenis penelitian}

Penelitian yang kami lakukan kali ini adalah penelitian yang berjenis penelitian eksperimental. penelitian eksperimen adalah penelitian yang dilakukan untuk mengetahui pengaruh pemberian suatu treatment atau perlakuan terhadap subjek penelitian dan menguji hipotesis tentang ada-tidaknya pengaruh tindakan itu jika dibandingkan dengan tindakan lain atau yang sama sekali tidak diberikan tindakan dengan kondisi yang terkendali. Penelitian ini kami lakukan di laboratorium Kimia SMA Negeri 1 Plupuh kabupaten sragen yang beralamat di jalan raya sambirejo - Plupuh Sragen

\subsection{Fokus Penelitian}

Penelitian ini difokuskan pada eksperimen untuk mempersingkat waktu pembuatan telur asin dengan melihat kemampuan kecepatan pemberian tekanan osmotic pada telur.

\subsection{Langkah kerja}

Urutan kerja dalam penelitian ini adalah sebagai berikut :

a. Memilih 5 telur itik kualitas prima dengan cara direndam dalam air diambil telur yang tenggelam, karena telur yang tenggelam menunjukkan kualitas telur baik.

b. membersihkan telur dengan air sampai bersih pada suhu kamar untuk menghilangkan semua kotoran yang menempel pada cangkang telur.

c. Mengambil 5 buah gelas kimia yang masing-masing diisi aquades, larutan asam cuka $5 \%$, larutan asam cuka $10 \%$, larutan asam cuka $15 \%$ dan larutan asam cuka $20 \%$ dan larutan asam cuka $25 \%$.

d. Masukkan 5 telur yang sudah terpilih ke dalam gelas kimia I,II,III,IV, dan V tunggu sampai 5 - 10 menit .

e. Ambillah kelima telur yang sudah direndam dalam Larutan I,II,III,IV,dan V kemudian bungkus dengan adonan serbuk bata merah, larutan garam dapur dan abu gosok dengan perbandingan garam dapur : serbuk bata merah : abu gosok 2:1:1.

f. Masukkan kelima bungkusan telur kedalam kantong plastik yang berbedabeda dan tandai dengan kertas label

g. Masukkan kelima kantung plastic yang berisi bungkusan adonan telur dalam alat pemanas, kemudian hubungkan dengan listrik

h. Tunggu sekitar 3 jam dan atur suhu sekitar $60^{\circ} \mathrm{C}$ dengan termometer, kemudian ambil kelima bungkusan tadi dengan cara mengangkat dari dalam pemanas.

i. Bersihkan sampai bersih telur sampai bersih dengan air. 
j. Belah kelima telur tadi dan uji PH larutan kelima telur tersebut, catat hasilnya

k. Rasakan kelima telur tersebut kemudian analisis hasilnya.

\section{HASIL DAN PEMBAHASAN}

\subsection{Keunggulan Kandungan Gizi Telur Asin}

Telur asin adalah istilah umum untuk masakan berbahan dasar telur yang diawetkan dengan cara diasinkan (diberikan garam berlebih untuk menonaktifkan enzim perombak). Kebanyakan telur yang diasinkan adalah telur itik, meski tidak menutup kemungkinan untuk telur-telur yang lain. Masa kadaluwarsa telur asin bisa mencapai 30 hari.

Telur adalah salah satu sumber protein hewani yang memilik rasa yang lezat, mudah dicerna, dan bergizi tinggi. Selain itu telur mudah diperoleh dan harganya murah. Telur dapat dimanfaatkan sebagai lauk, bahan pencampur berbagai makanan, tepung telur, obat, dan lain sebagainya. Telur terdiri dari protein $13 \%$, lemak $12 \%$, serta vitamin, dan mineral. Nilai tertinggi telur terdapat pada bagian kuningnya. Kuning telur mengandung asam amino esensial yang dibutuhkan serta mineral seperti : besi, fosfor, sedikit kalsium, dan vitamin B kompleks. Sebagian protein (50\%) dan semua lemak terdapat pada kuning telur. Adapun putih telur yang jumlahnya sekitar $60 \%$ dari seluruh bulatan telur mengandung 5 jenis protein dan sedikit karbohidrat. Hampir semua lemak dalam sebutir telur itik terdapat pada bagian kuningnya, mencapai 35 persen, sedangkan di bagian putihnya tidak ada sama sekali. Lemak pada telur terdiri dari trigliserida (lemak netral), fosfolipida (umumnya berupa lesitin), dan kolesterol. Fungsi trigliserida dan fosfolipida bagi tubuh adalah sebagai sumber energi, satu gram lemak menghasilkan 9 kilokalori energi. Lemak dalam telur berbentuk emulsi (bergabung dengan air), sehingga menjadi lebih mudah dicerna, baik oleh bayi, anak-anak, maupun golongan lanjut usia.

\subsection{Keunggulan Teknik Pengasinan Telur.}

Tujuan pengawetan telur adalah untuk mengurangi jumlah awal sel jasad renik didalam telur, memperpanjang fase adaptasi semaksimum mungkin sehingga pertumbuhan mikroba diperlambat, memperlambat fase pertumbuhan logaritmik, dan mempercepat fase kematian mikroba.

Prinsip pengawetan telur adalah untuk :

1. Mencegah masuknya bakteri pembusuk ke dalam telur;

2. Mencegah keluarnya air dari dalam telur.

Cara pembuatan telur asin dengan menggunakan adonan garam akan menghasilkan telur asin yang jauh lebih bagus mutunya, warna lebih menarik, 
serta cita rasa yang lebih enak. Garam berfungsi sebagai pencipta rasa asin dan sekaligus bahan pengawet karena

dapat mengurangi kelarutan oksigen (oksigen diperlukan oleh bakteri), menghambat kerja enzim proteolitik (enzim perusak protein), dan menyerap air dari dalam telur. Berkurangnya kadar air menyebabkan telur menjadi lebih awet karena air digunakan oleh mikroorganisme untuk pertumbuhan. Pada umumnya konsentrasi garam 10-15\% sudah cukup untuk membunuh sebagian besar jenis bakteri dan mikroba.

Pengasinan telur umumnya dilakukan dengan dua cara, yaitu perendaman dalam larutan garam dan pemeraman oleh adonan campuran garam dengan tanah liat, atau abu gosok atau bubuk bata merah Prinsip kedua cara tersebut adalah dehidrasi osmosis, yaitu proses pengurangan air dari bahan dengan cara membenamkan bahan dalam suatu larutan ber- konsentrasi tinggi, larutan tersebut mempunyai tekanan osmosis tinggi. Dehidrasi osmosis (osmotic dehydration) merupakan proses perpindahan massa secara simultan antara keluarnya air dari bahan dan zat terlarut berpindah dari larutan ke dalam bahan. Aplikasi dehidrasi osmosis dalam proses pengasinan, terlihat dengan keluarnya air dari dalam telur bersamaan dengan masuknya larutan garam ke dalam telur. Garam ( $\mathrm{NaCl}$ ) akan masuk ke dalam telur dengan cara merembes melalui poripori kulit, menuju ke bagian putih, dan akhirnya ke kuning telur. Garam $\mathrm{NaCl}$ mula-mula akan diubah menjadi ion natrium $\left(\mathrm{Na}^{+}\right)$dan ion chlor $\left(\mathrm{Cl}^{-}\right)$. Ion chlor inilah yang sebenarnya .berfungsi sebagai bahan pengawet, dengan menghambat pertumbuhan mikroba pada telur. Makin lama dibungkus dengan adonan, makin banyak garam yang merembes masuk ke dalamnya, sehingga telur menjadi semakin awet dan asin. Lamanya telur dibungkus adonan ini harus disesuaikan dengan selera masyarakat yang akan mengonsumsinya.

\subsection{Keunggulan Teknik Pembuatan Telur Asin Selama 3 jam}

Selama ini telur asin dibuat membutuhkaan waktu selama 2 pekan ( 15 hari ). Kami melakukan terobosan dengan efek tekanan osmotik dan perendaman dapat mempercepat pembuatan telur asin. Langkah langkah proses pembuatan sebagai berikut:

1. Pemilihan kualitas telur yang prima dengan ciri ciri apabila telur direndam dalam air telur akan tenggelam. Perlakuan ini dilakukan bertujuan untuk memilih kualitas yang baik karena sebagai bahan makanan sumber protein tinggi.

2. Proses perendaman dalam asam cuka dengan variabel percobaan larutan cuka $5 \%, 10 \%, 15 \%, 20 \%$,dan $25 \%$. Kegiatan ini bertujuan untuk membuka/ memperbesar pori cangkang telur agar proses osmotik garam lebih cepat . Hasil 
percobaan yanag diperoleh ternyata semakin tinggi kadar asam cuka tingkat osmosis garam lebih cepat dan rasa dari telur semakin asin.

3. Proses pembungkusan telur dengan adonan abu gosok yang dicampur dengan serbuk bata merah dan garam serbuk. Proses ini dilakukan agar garam dapat masuk melalui cangkang telur yang telah diperbesar agar tekanan osmotik garam lebih besar maka suhu kita atur sekitar $60-70^{\circ}$ Celsius supaya telur tidak masak terlebih dahulu.

4. Setelah 3 jam kemudian telur diambil dan dibersihkan kemudian kita cek tingkat keasaman, untuk mengetahui apakah dalam proses perendaman dalam larutan asam cuka mempunyai efek asam cuka ikut masuk ke cangkang telur, ternyata hasil yang diperoleh $\mathrm{pH}$ telur $=6,8$ artinya proses perendaman dalam asam cuka tidak mempengaruhi tingkat keasaman telur. Ini menunjukkan telur aman dikonsumsi. Sebagai bahan pembanding agar $\mathrm{pH}$ dengan telur yang tidak direndam daalam asam cuka ternyata memberikan harga $\mathrm{pH}$ sama.

\subsection{Keunggulan Penelitian Dengan Penelitian Sebelumnya.}

Keunggulan dari Penelitian ini di antaranya :

1. Memberikan solusi teknik Pengawetan makanan secara alami yang aman, higenis untuk dikonsumsi.

2. Teknik Pembuatan telur asin dari hasil penelitian ini dapat digunakan oleh siapa saja karena caranya mudah, bahan baku murah dan mudah didapat dimana-mana.

3. Spesifikasi teknik penelitian ini mudah dilakukan oleh siapa saja sehingga tidak bertele tele untuk melakukannya.

4. Cita rasa yang diinginkan sesuai selera tinggal memanipulasi kandungan garam dan lama perendaman dalam asam cuka.

5. Memberikan solusi untuk diproduksi massal terutama di wilayah sentra peternak itik untuk meningkatkan nilai ekonomi kerakyatan.

6. Nilai produktivitas tinggi karena waktu yang dibutuhkan relative singkat yang selama ini butuh waktu sampai 15 hari.

7. Perendaman dalam larutan asam cuka tidak mempengaruhi tingkat keasaman telur terbukti hasil pengukuran $\mathrm{pH}$ dari telur yang direndam dalam air dan dalam larutan asam cuka menghasilkan data yang sama yaitu $\mathrm{pH}=6,8$.

8. Proses Perendaman dengan larutan asam cuka mampu mempercepat laju osmosis garam masuk dalam cangkang telur.

9. Meningkatkan nilai perekonomian masyarakat akar rumput sehingga mampu menopang usaha mikro dan menengah.

\subsection{Penerapan Pada Masyarakat dan Industri}

Hasil dari penelitian ini diharapkan dapat diterapkan Untuk : 
1. Pemenuhan kebutuhan gizi masyarakat karena kandungan gizi telur cukup tinggi.

2. Masyarakat dapat menggunakan teknologi ini sebagai home industry di rumah rumah untuk bahan makanan lauk pauk sumber protein tinggi

3. Memenuhi permintaan kebutuhan telur asin di masyarakat karena selama ini permintaan dan tersedianya barang tidak seimbang.

4. Konsep hasil penelitian ini dapat diproduksi oleh industry secara masal karena biaya produksi murah dan nilai jual tinggi sehingga nilai ekonominya cukup tinggi.

\subsection{Prospek Pengembangan Ke Depan.}

Prospek pengembangan ke depan dari penelitian ini adalah :

1. Variasi rasa telur asin disesuaikan dengan kebutuhan pasar karena hanya cukup memanipulasi lama perendaman dalam larutan asam cuka dan kadar garamnya.

2. Variasi kemasiran telur dapat dibuat dengan cara mengurangi kadar air dalam adonan pembungkus telur .

3. Pemanas yang digunakan dapat dari limbah uap proses industry pembuatan tahu sehingga nilai produktivitas tinggi selain produksi tahu disisi lain dapat menghasilkan telur asin.

4. Variasi pemanas yang digunakan dapat juga menggunakan cerobong asap dari gas hasil buang proses pembuatan bata merah .

5. Ke depan diharapkan industry dan pemerintah dapat mendorong warga masyarakat untuk memproduksi alat yang lebih praktis lagi untuk menyempurnakan penelitian ini

\section{PENUTUP DAN KESIMPULAN}

\subsection{KESIMPULAN}

1. Pengaruh tekanan osmotik dapat mempercepat proses pembuatan telur asin.

2. Proses Perendaman telur dalam larutan aasam cuka berfungsi membuka pori cangkang telur agar proses osmosis gaaram lebih cepat

3. Pembutan telur asin dapat dibuat daalam waktu 3 jam.

\subsection{SARAN}

1. Agar percobaan ini lebih dikembangkan lagi dalam skala industri

2. Supaya dinas terkait mendukung penelitian lebih lanjut untuk menumbuh kembangkan jiwa penelitian.

3. Penulis berharap makalah ini dapat menjadi salah satu bahan bacaan yang bermanfaat bagi para pembaca yang haus akan ilmu dan keterampilan, untuk 
dapat mempersiapkan diri dalam kompetisi persaingan yang sehat dalam hal penciptaan peluang kerja yang produktif.

\section{DAFTAR PUSTAKA}

Kautsar I. 2005. Pengaruh lama perendaman dalam larutan asam asetat 7\% dan lama perendaman terhadap beberapa karakteristik telur asin. [Skripsi]. Fakultas Pertanian Universitas Padjadjaran: Jatinangor.

Sultoni A. 2004. Pengaruh konsentrasi larutan asam asetat dan lama perendaman terhadap beberapa karakteristik telur asin dari telur itik Jawa Anas javanicus. [Skripsi]. Fakultas Pertanian Universitas Padjadjaran : Jatinangor

Sukendra L. 1976. Pengaruh cara pengasinan telur bebek Muscovy sp dengan menggunakan adonan campuran garam dan bata terhadap mutu telur asin selama penyimpanan.[Skripsi]. Fakultas Mekanisasi dan Teknologi Hasil Pertanian-IPB: Bogor

http://www.praktikumbiologi.com/2011/06/contoh-format-laporan-praktikumbiologi.html

http://biolaeksisdiyannyuska.blogspot.com/2011/03/laporan-praktikum-biologiterapan.html

http://sudut-bacaan.blogspot.com/2013/11/ragam-cara-membuat-telur-asinsederhana.html

http://www.likethisya.com/cara-membuat-telur-asin-mudah-dan-enak.html

http://deboraprimera.blogspot.com/2012/05/proses-yang-terjadi-padasaat.html

http://diana11oktober.blogspot.com/2013/10/telur-asin.html

http://imgianni.blogspot.com/2013/07/makalah-telur-asin.html

http://www.republika.co.id/berita/gaya-hidup/kuliner/14/06/04/n6mwqa-maubikin-telur-asin-ini-caranya

http://id.wikipedia.org/wiki/Osmosis 


\section{LAMPIRAN GAMBAR}

Lampiran gambar Praktikum :

1. Proses Pemilihan kualitas telur yang baik

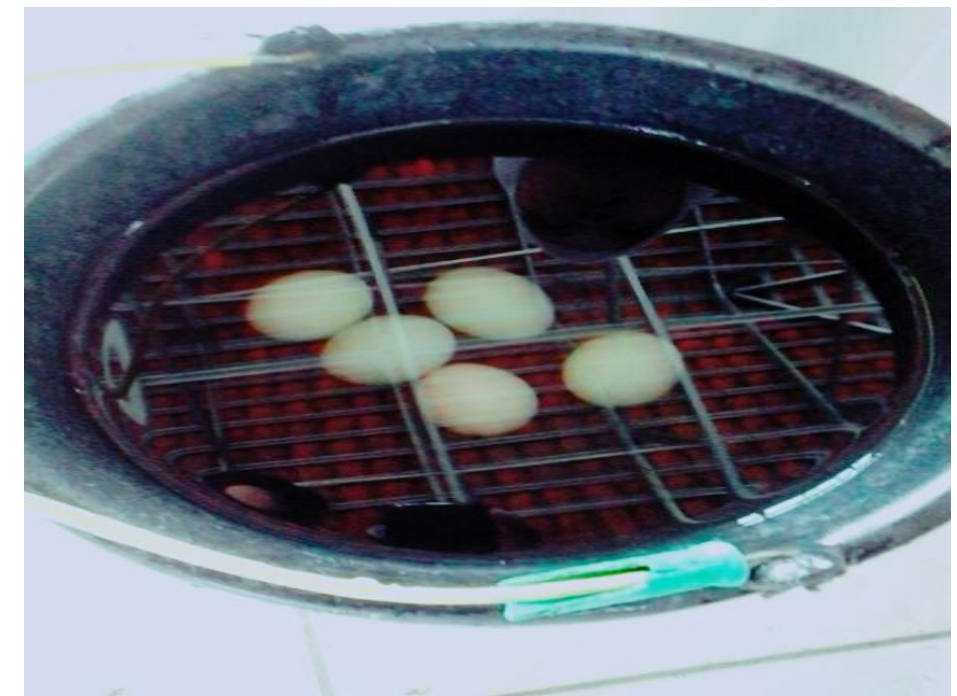

2. Proses perendaman dalam larutan asam cuka

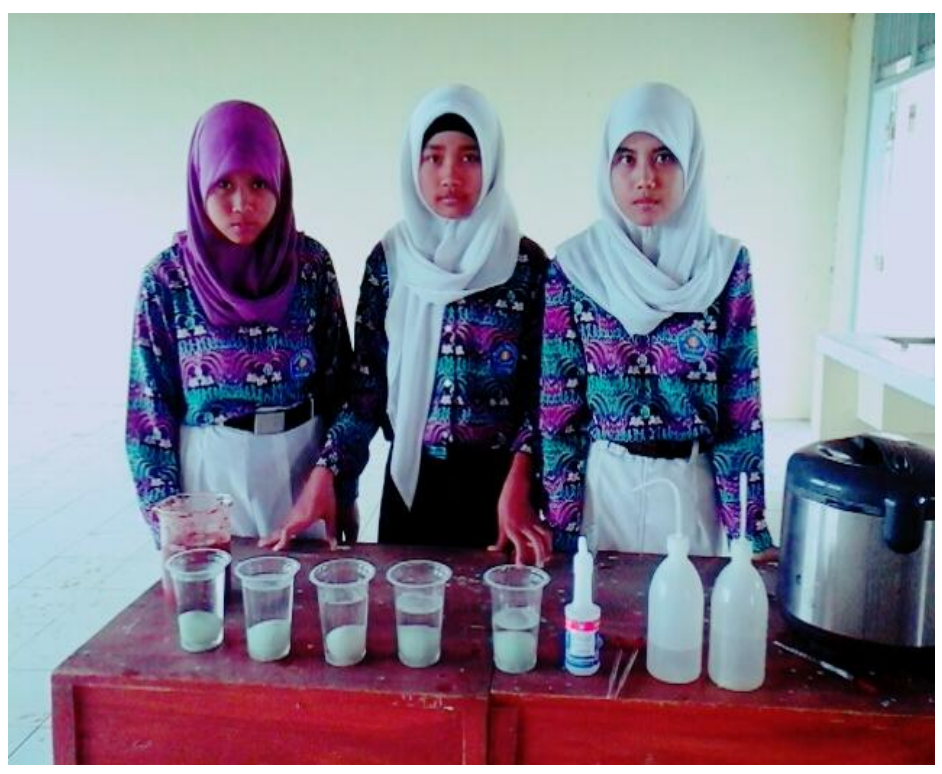


3. Proses Pembungkusan telur dalam adonan Garam Dapur: Serbuk bata merah : serbuk abu gosok $=2: 1: 1$

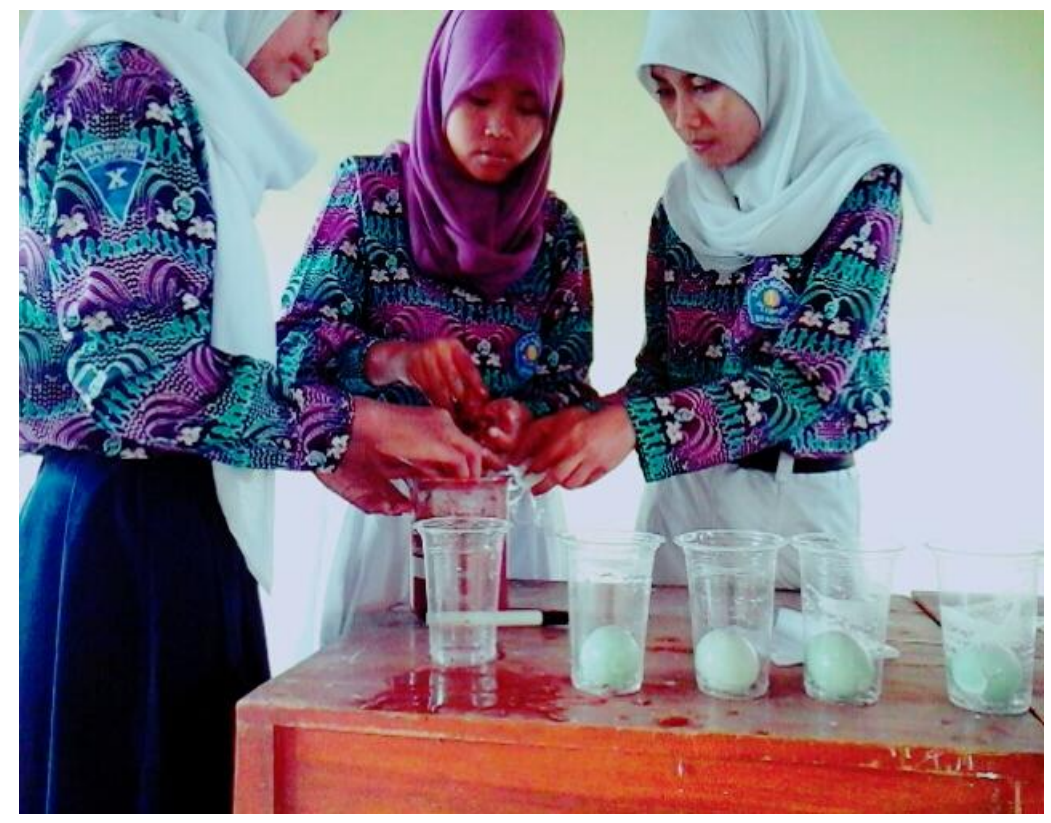

4. Adonan siap dimasukkan dalam pemanas

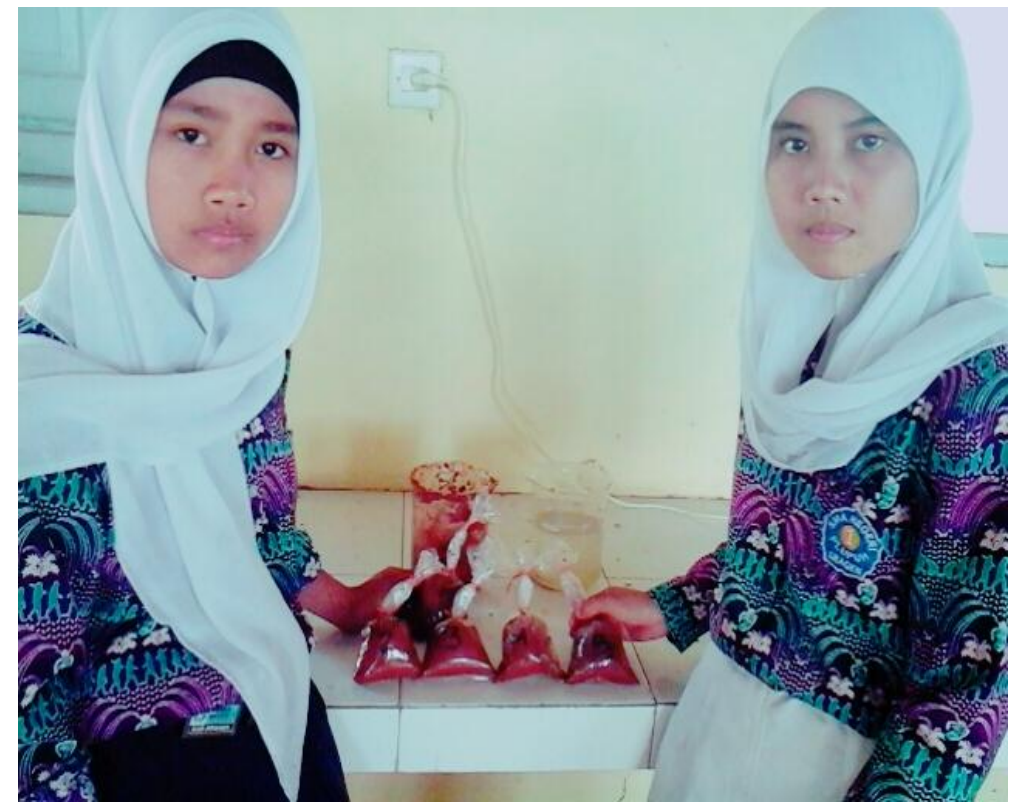


5. Proses Pemanasan telur pada suhu $60^{\circ} \mathrm{C}$

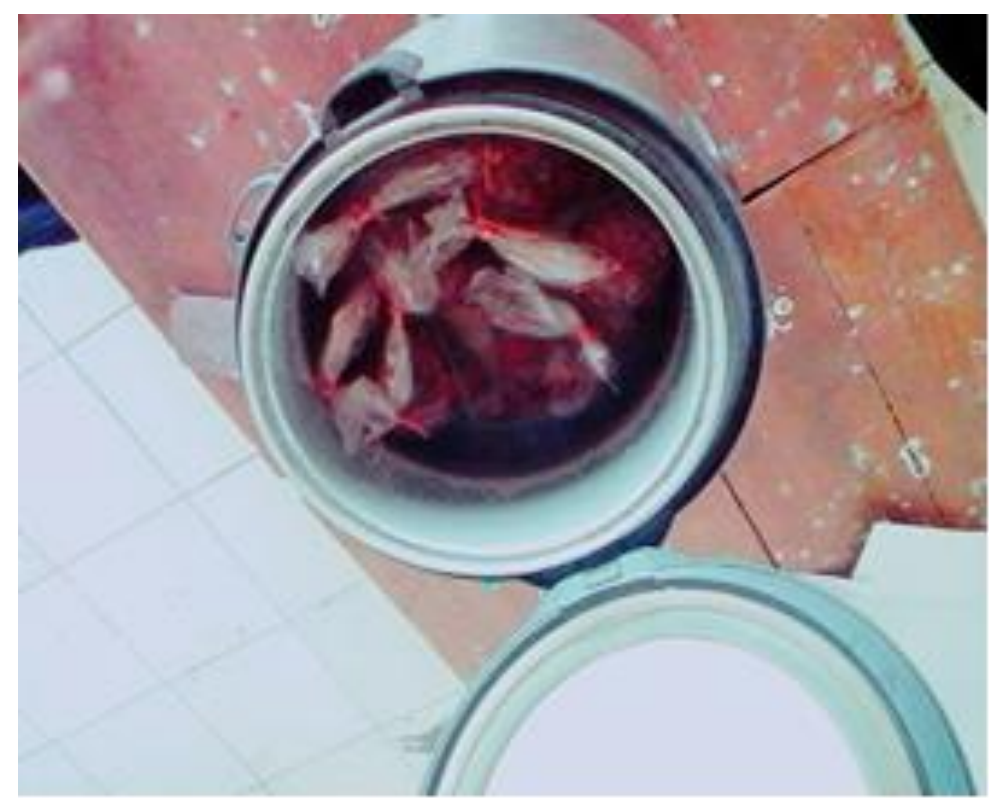

6. Telur siap dihidangkan

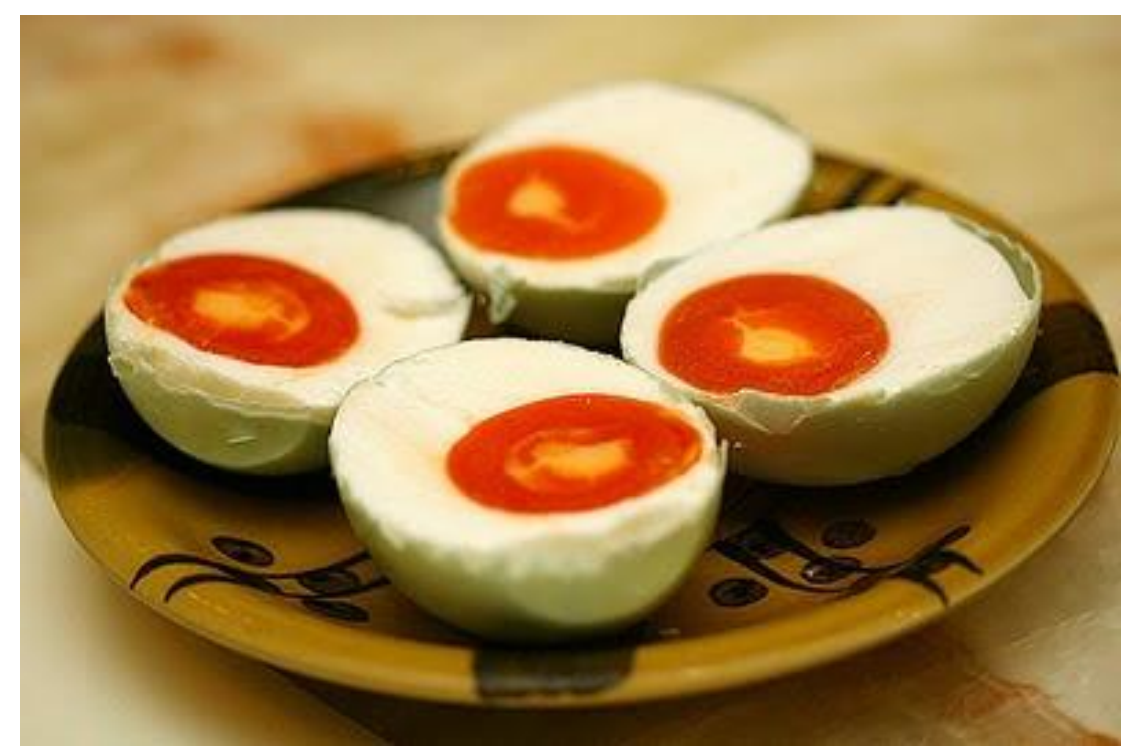

